$$
\begin{aligned}
& 4 . \\
& 615.789: 612.544 \\
& 2,3 \text { 交感神經毒ノ體溫二及ボス影翌 } \\
& \text { 殊 二霻溫下降作用二就テ }
\end{aligned}
$$

岡山需科大學藥物學票室 (主任奥島嚾)

医罢士 藤 野 源 三

[昭和 6 年 6 月 6 日受简]

\begin{abstract}
Über die Wirkung einiger Sympathicusgifte auf die Körpertemperatur, besonders über ihre temperaturerniedrigende Wirknng.

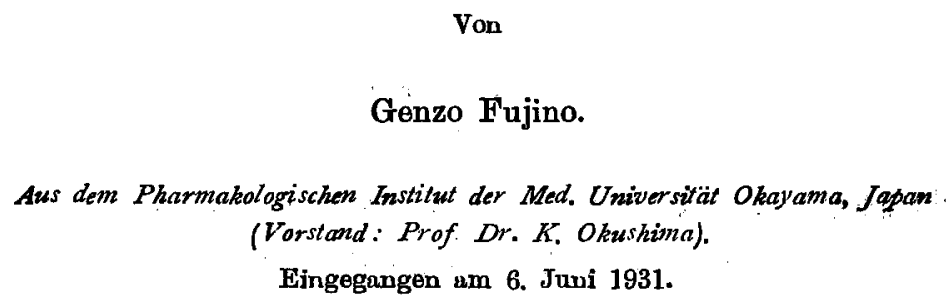

Es wurde die Wirkung einiger Sympathicusgifte, wie Adrenalin, Adrenalon, Ephedrin und Tetrahydro- $\beta$-naphthylamin auf die Körpertemperatur des Kaninchens untersucht. Diese Sympathicusgifte zeigen im allgemeinen eine doppelte Wirkung, eine erniedrigende und eine steigernde. Je nach der Applikationsstelle oder der Dose des Giftes und auch nach der Irdividualität des Tieres tritt die die Körpertemperatur herabsetzende oder steigernde Wirkung auf. Jedoch kann man die Resultate, wie folgt, kurz zusammenfassen.

I. Bei subcutaner und intravenoser Darreichung:

1. Adrenalin wirkt in kleinen Dosen auf die Korpertemperatur steigernd, in grossen Dosen dagegen erniedrigend. Beide Wirkungen sind bei intravenoser Injektion deutlicher als bei subcutaner.

2. Im Gegensatz zum Adrenalin wirken Adrenalon, Ephedrin, und Tetra. auf die Korpertemperatur in kleinen Dosen herabsetzend, in grossen Dosen steigernd, und beide Wirkungen sind bei subcutaner Injektion deutlicher als bei intravenoser.

3. Nach der Stärke ihrer temperaturerniedrigenden Wirkung ordnen sich die untersuchten Gifte in folgender Reihe: Adrenalin $>$ Adrenalon $>$ Tetra. $>$ Ephedrin. Das Adrenalin ist hinsichtlich der temperaturerniedrigenden Wirkung $10-20$ mal so stark wie Adrenalon. 
4. Nach der Stärke der temperatursteigernden Wirkung ordnen sich die Gifte in folgender Reihe: Adrenalin $>$ Tetra. $>$ Ephedrin $>$ Adrenalon. Die wirksame Mini maldosis des Adrenalons ist dabei $1000 \mathrm{mal}$ so gross wie die des Adrenalins. Daraus ergibt sich, dass das Adrenalon in der temperaturherabsetzenden Wirkung relativ viel stärker ist als in der temperatursteigernden, wenn man es mit Adrenalin vergleicht.

II. Bei intracerebraler Injektion :

1. Adrenalin (bis $0.1 \mathrm{mg}$ pro $\mathrm{kg}$ ) wirkt auf die Korpertemperatur steigernd oder übt keinen Einfluss aus.

2. Adrenalon, Ephedrin, und Tetra setzen die Körpertemperatur deutlich herab. Diese Wirkung ist mitunter bei Ephedrin am deutlichsten, dann folgt Tetra und Adrenalon ist am schwächsten.

Aus den oben angegebenen Ergebnissen erkennt man, dass diese Sympathicusgifte nicht nur auf die Temperatur steigernd, sondern auch erniedrigend wirken, und dass die letztere Wirkung im wesentlichen zentral bedingt ist. Nur beim Adrenalin wurde eine zentrale temperatursenkende Wirkung nicht direkt nachgewiesen, obwohl es dem Verfasser schien, dass das Adrenalin auch diese Wirkung besitzt.

Die Tatsache, dass Symathicusgifte auch eine zentrale temperaturerniedrigende Wirkung haben, stimmt mit dem Befund der früheren Untersuchung des Verfassers über den Einfluss des Atropins und der Durchschneidung des N. vagus auf die temperaturerniedrigende Wirkung der Krampfgifte sowie mit der Mitteilung von Rosenthal etc. über die Existenz temperaturdämpfender stoffwechselhemmender Rückenmarksbahnen überein. Daraus dürfte geschlossen werden, dass das sympathische Nervensystem an dem Mechanismus der Temperatursenkung beteiligt ist und das sog. Küblzentrum, welches seit $H$. Meyer im allgemeinen als parasympathisch angenommen wird, mehr sympathischer Natur ist. (Kurze Inhaltsangabe).

屉

緒 言

实毁材料立方法

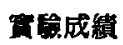

I 皮下注射

1.「アドレナリン」

2.「ナドレナロン」

3.「エフェドリン」

4.「テトラヒドロふータナフチールフミン」

II 靜䀠內这射

同上

III 膘踏內注射
容

\section{A. 對照㭡殿}

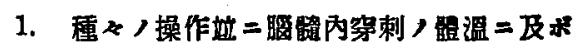
入影暗

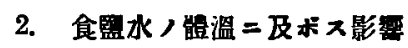

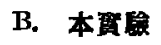

1. 「テドレナリン」

2. 「フドレナロン」

3.「エフエドリン」

4. 「テトラヒドロデタナフチールフミン」

綪括站二考察

結 諭 


\section{緒}

言

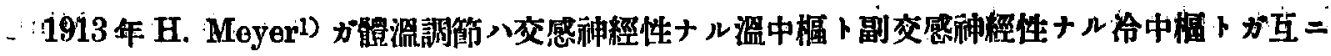

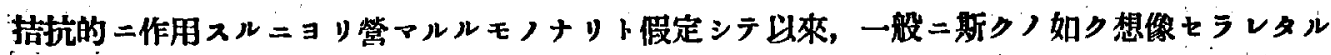

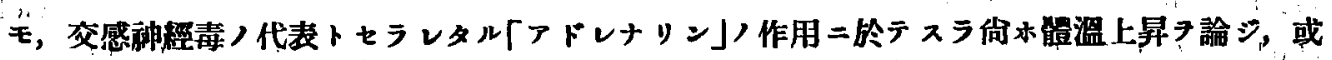

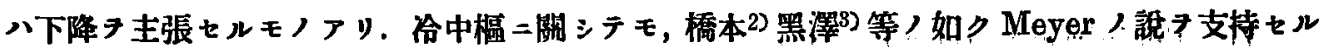

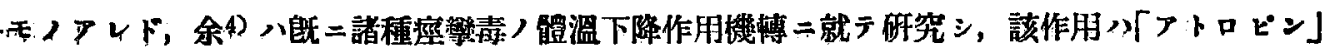

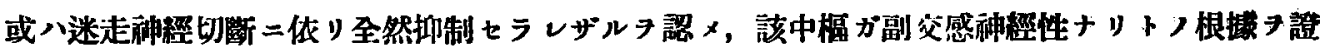

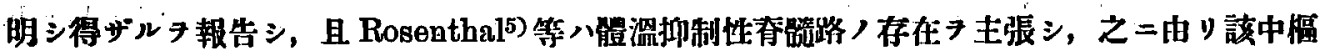
公蜜口交感神經性ナラント推諭セり。

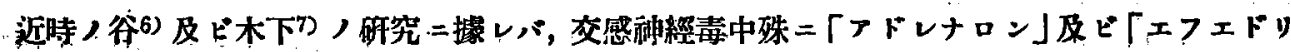

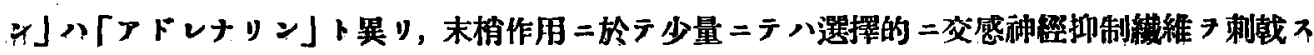

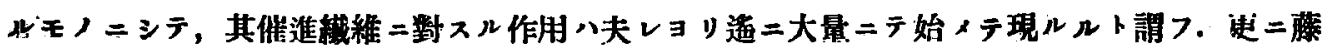

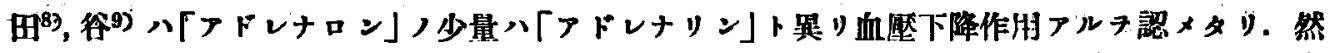

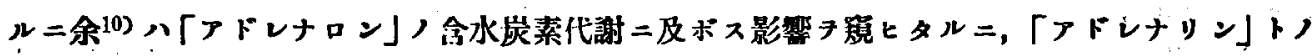

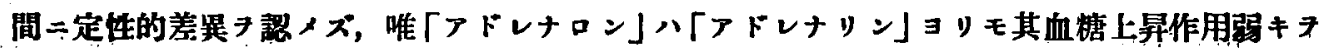

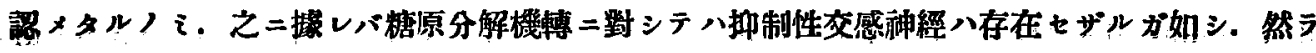

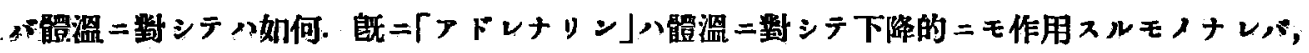

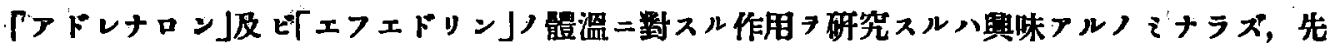

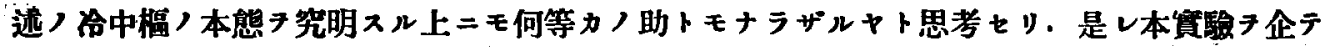

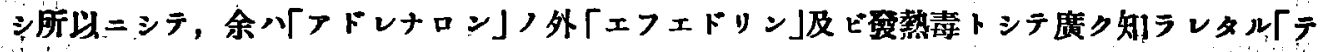

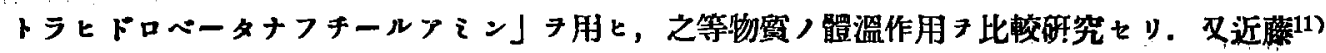

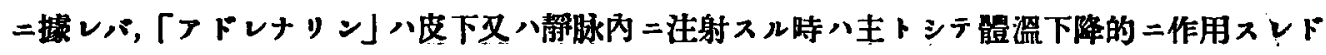

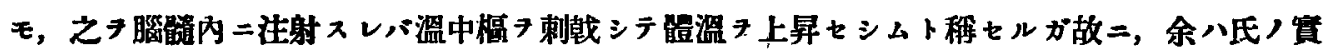

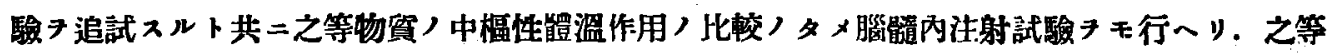

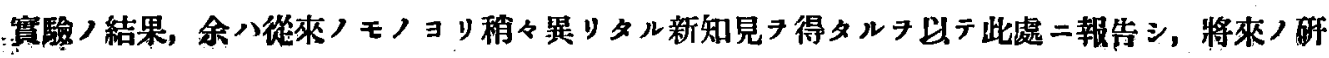
究ノ一助トナサントス。

\section{實驗材料端二方法}

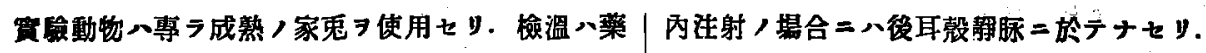

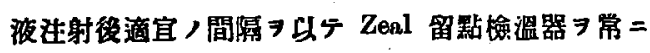

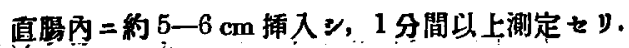

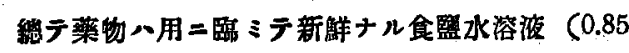

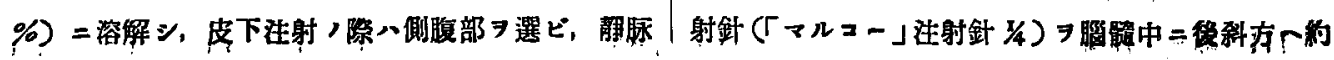

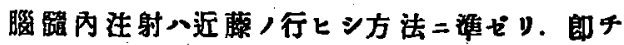
Aronsohn-Sichs ${ }^{12}$ 氏 溫刺二於ンルト同一斯所二於

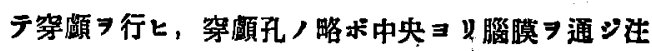




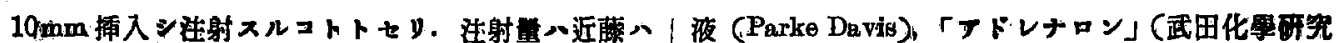

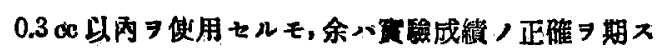
ルメ常 $=0.1$ c $\mathrm{kg}$ 便用セり.

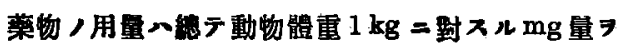
日广訅载七y.

部)、監酸「エフエドリン」(日本製柇)、監酸「マト。 ラヒドロヘータナフチールフミン」（武田化學研究 部).

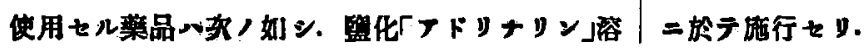

\section{實 驗 成 綪}

\section{I 皮下 注 射}

1.「アドレナリン」

「テドレナリン」ノ顝溫作用二阙シテハ古來多數 ノ 研究厂 y. Freund u. Grafe13)，橋本, Adler ${ }^{14)}$, 吉

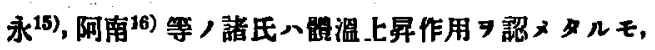

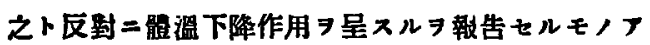
y (Wolowniki7), Abderhalden ${ }^{18)}$, 山內 ${ }^{19)}$, 田中 ${ }^{20)}$. 然 $ル=$, Döblin u. Fleisøhmann ${ }^{21)}$, Cloettr u. Wrser ${ }^{22)_{i}}$

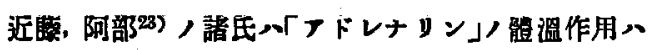

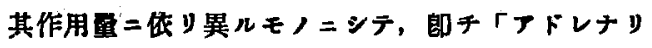

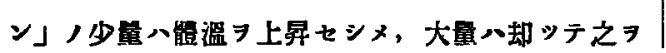

下降セシムト糐セり.

余ハ「ドレナリン」ノ理やノ星习家兔ノ皮下二注

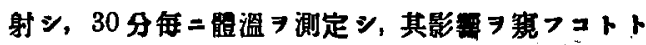

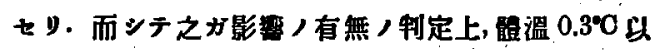
上ノ動搜 7 以テ上昇或八下降セルモノトナシ, 十或

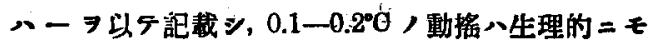
存在スル 以テ，上昇或、下降,傾向 7 宗スそノト ナシ、(十)又ハ(一)

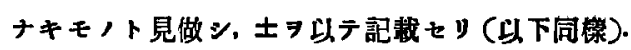

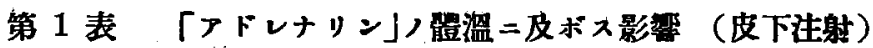

\begin{tabular}{|c|c|c|c|c|c|}
\hline \multicolumn{2}{|c|}{ 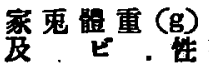 } & 注射基 (mg) & $\begin{array}{l}\text { 最大下降，上昇度 } \\
=\text { 䢖入ル迄，時間 }\end{array}$ & 最大毞度 (C) & 正常温，迤久 \\
\hline 1900 & $\boldsymbol{s}$ & 0.05 & & $(+)$ & \\
\hline 1950 & $q$ & $"$ & 0.5 時間 & $+0.3^{\circ}$ & 1 時間 \\
\hline 2200 & ㅇ & $\Rightarrow$ & 1 時間 & $+0.3^{\circ}$ & 1 時間 \\
\hline 1950 & $\delta$ & 0.1 & & $(-)$ & \\
\hline 2000 & $\widehat{\delta}$ & 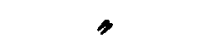 & & $(-)$ & \\
\hline 2250 & ㅇ & $"$ & 1.5 時間 & $-1.3^{\circ}$ & 3.5 時間 \\
\hline 2100 & 9 & 0.2 & & $(-)$ & \\
\hline 1800 & $\hat{\delta}$ & " & 2 時間 & $-0.4^{\circ}$ & 2 時間 \\
\hline 2000 & 8 & $"$ & $\left\{\begin{array}{r}0.5 \text { 時間 } \\
2\end{array}\right.$ & $\begin{cases}+ & 0.3^{\circ} \\
- & 0.8^{\circ}\end{cases}$ & 2 時間 \\
\hline 1950 & $\hat{\mathbf{o}}$ & 0.5 & 2.5 時間 & $-0.5^{\circ}$ & 2 時間 \\
\hline 2000 & of & $"$ & 1 時間 & $-0.6^{\circ}$ & 2 時間 \\
\hline 2250 & ㅇ & $\Rightarrow$ & & $(+)$ & \\
\hline 1900 & $q$ & 1 & 3.5 時間 & $-0.4^{\circ}$ & 1.5 時間 \\
\hline 2050 & 8 & $\Rightarrow$ & 2.5 時間 & $-0.6^{\circ}$ & 2.5 時間 \\
\hline 2150 &.$ㅇ$ & $\Rightarrow$ & 5 時間 & $-2.8^{\circ}$ & 㯊死 \\
\hline
\end{tabular}

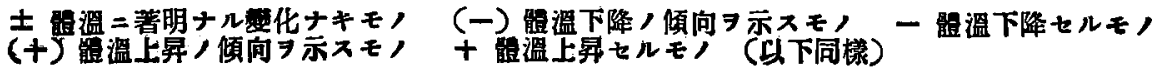


即于第1表二示をルガ奶ク「「ドレナリン」0.05mg

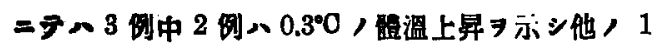

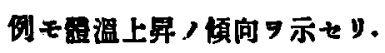

「ナドレナリン」0.1 mg ニテの以上ノ如キ體溫上 显作用

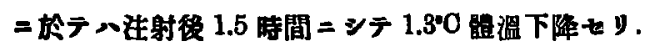

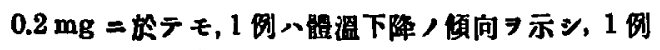

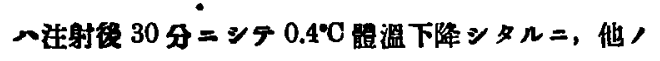

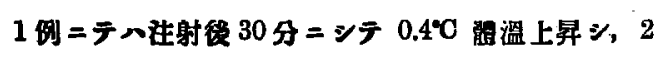
時間ニシテ却ッテ $0.8 \bullet 0$ 下降セり。

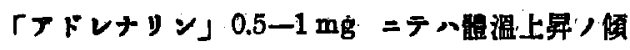

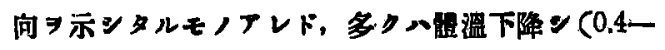

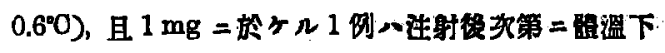
降シ，後動物八整死セり。

以上ノ如ク、「フトレナリン」习皮下泩射ンタル，

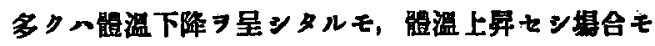
エリ. 而シテ該作用八量的關係ヨリモ寧口個任二恢 リ著シク異ナル方如キモ，一般二多量八䨩温 セシメ，大皇ハ之テ下降セシムルガ如シ. 此點上記 近藤，阿部等，成䋶卜相似，

\section{2.「フドレナロン」}

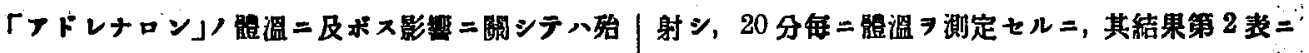

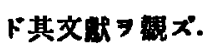
於ヶルガ如シ.

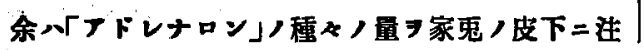

第 2 表「フドレナロン」體溫二及ボス影劉（皮下注射）

\begin{tabular}{|c|c|c|c|c|c|}
\hline \multicolumn{2}{|c|}{ 家电福軍 (跣) } & 注射 $(\mathrm{mg})$ & 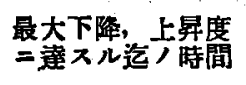 & 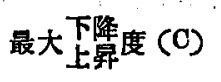 & 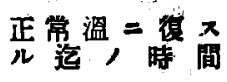 \\
\hline 1850 & 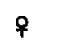 & 1 & & $(-)$ & \\
\hline 1910 & $\hat{\delta}$ & 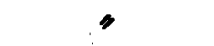 & 1 時間 20 分 & $-0.4^{\circ}$ & 1 時間 40 分 \\
\hline 2050 & $\delta$ & " & 40 分 & $-0.5^{\circ}$ & 1 時間 20 分 \\
\hline 1750 & q & 2 & & $(-)$ & \\
\hline 1880 & ? & , & 1 時間 & $-0.4^{\circ}$ & 1 時間 20 分 \\
\hline 1970 & $\hat{o}$ & ? & 1 時間 20 分 & $-0.3^{\circ}$ & 40 分 \\
\hline 2000 & $\hat{\beta}$ & 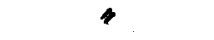 & 1 時間 & $-0.3^{\circ}$ & 1 時闍 \\
\hline 2100 & $\hat{\delta}$ & - & 1 時間 & $-0.4^{\circ}$ & 1 時間 \\
\hline 2190 & q & 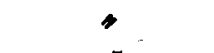 & 1 時間 & $-0.3^{\circ}$ & 1 時間 20 分 \\
\hline 1740 & 9 & $\check{\mathbf{o}}$ & & $(-)$ & \\
\hline 1920 & 9 & 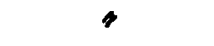 & 1 時間 & $-0.3^{\circ}$ & 1 時間 20 分 \\
\hline 2000 & $q$ & , & & \pm & \\
\hline 2000 & $\delta$ & 10 & 1 時間 & $-0.3^{\circ}$ & 1 時間 40 分 \\
\hline 1800 & $\hat{\delta}$ & , & & \pm & \\
\hline 2000 & $\delta$ & ? & & \pm & \\
\hline 1780 & $\delta$ & 20 & 1 時間 20 分 & $-0.3^{\circ}$ & 1 時間 40 分 \\
\hline 1800 & 9 & $\diamond$ & & \pm & \\
\hline 2000 & $\boldsymbol{\delta}$ & 50 & & \pm & \\
\hline 2050 & 8 & 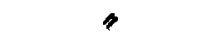 & 1 時間 & $+0.5^{\circ}$ & 4 時間以上 \\
\hline
\end{tabular}

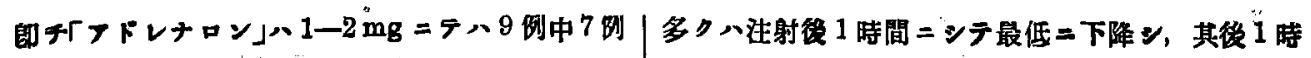

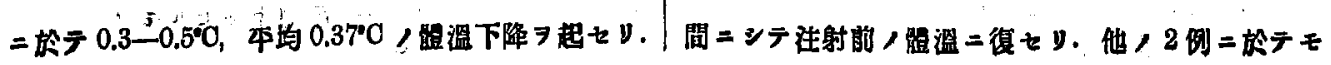




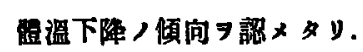

「フドレナロン」5-20 mg =テハ8例中 3 侧心泩

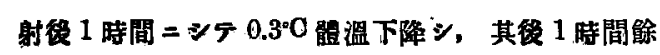
ニシテ正常温二復シタルモ, 他 二著明ナル影整ナカリキ.

更=「アドレナロン」50 mg 7 試ミタルニ, 1 例 $=$

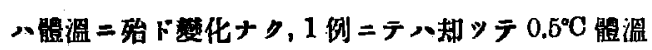

上昇セり．尚ホ表中二ふ少略シタレドモ「「ドレナ ロン」.0.5 mg ニテハ體溫下降ノ㑯向ヨ示シタルノミ

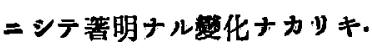

斯りノ姐ク，「ナトレナロン小皮下法射ニテハタ

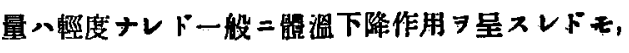

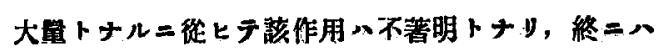
却ッテ䯠溫 ヨ上昇セシム。

$$
\text { 3.「ェフェドリン」 }
$$

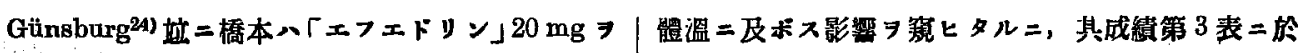

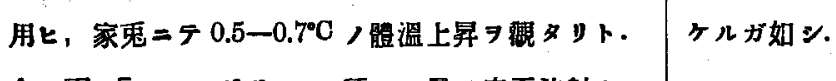
余八更

第 3 表 「ェフェドリン」/體溫二及ボス影䡉（皮下注射）

\begin{tabular}{|c|c|c|c|c|c|}
\hline 家鬼骨雴 & (g) & 注射量 $(\mathrm{mg})$ & $\begin{array}{l}\text { 最大下阵, 上昇度 } \\
=\text { =洋スル迄，時間 }\end{array}$ & 最大罂度 (C) & 正常温，㣱 $\underset{\text { 間 }}{ }$ \\
\hline 1890 & $\delta$ & 5 & 1.5 時間 & $-0.3^{\circ}$ & 2.5 時間 \\
\hline 2020 & $\hat{\delta}$ & $"$ & 2 時間 & $-0.4^{\circ}$ & 2 時間 \\
\hline 1900 & $\delta$ & $\Rightarrow$ & & \pm & \\
\hline 2110 & 우 & $"$ & 1 時間 & $+0.3^{\circ}$ & 1.5 時間 \\
\hline 1770 & $\delta$ & 10 & & $(-)$ & \\
\hline 2000 & $\delta$ & 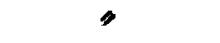 & 1.5 時間 & $-0.5^{\circ}$ & 3 時間 \\
\hline $\mathbf{1 7 9 0}$ & q & 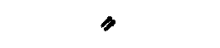 & 0.5 時間 & $+0.3^{\circ}$ & 1.5 時間 \\
\hline 2080 & $\delta$ & $"$ & 2.5 時間 & $+0.4^{\circ}$ & 3 時間 \\
\hline 1820 & 우 & 20 & 0.5 時間 & $+0.3^{\circ}$ & 4 時間以上 \\
\hline 1980 & ? & $"$ & 2 時間 & $+0.4^{\circ}$ & 3 時閻 \\
\hline 2030 & $\delta$ & 50 & 3 時間 & $-0.3^{\circ}$ & 0.5 時間 \\
\hline 1890 & $\hat{o}$ & 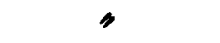 & 0.5 時間 & $+0.4^{\circ}$ & 3 時間 \\
\hline 1780 & $\hat{\alpha}$ & 100 & 0.5 時間 & $+0.6^{\circ}$ & 6 時間以上 \\
\hline 2020 & o & " & 3 時間 & $+0.3^{\circ}$ & 3 時間以上 \\
\hline
\end{tabular}

即チ「ェフェドリン」5-10 mg ニテハ8 例中 3 例 ニテハ注射後 1 時間 シシテ $0.3-0.4^{\circ} \mathrm{C}$ 體温上昇セリ.

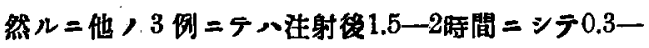
$0.5^{\circ} \mathrm{C}$ 體温下隐 $ォ, 2-3$ 時間ニシテ何レモ正常溫二 復セリ. 问木體温二砝ド影響ナキモノ，或心體溫下 降/傾向习呈セルモノ各飞 1 例ナリタリ.

「エフェドリン」20 mg ニテハ2例トモ0.3-0.4

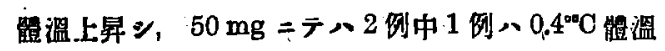

下降シ，他八注射後 30 分 $=シ テ 0.4^{\circ} \mathrm{C}$ 體溫上舁セリ。 $100 \mathrm{mg}$ 二テモ2 2 挒二於テ何レモ體温上昇セり。

斯ク，如ク，「ェフェドリン」ハ少量二テ體溫ョ下 隆セシムル場合卜反到二之ョ上昇セシムル堨合トア リ. 郎チ「ェフェドリン」ハ少量ニテハ體溫下降及ビ 上昇ノ雨作用习有スルモノ，如》，大量トナルニ從 ヒテ,「テドレナロン」ト同樈, 其體溫下降作用八不

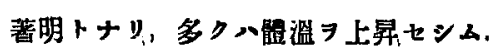




\section{4.「テトラヒドロベータナフチールフミン」}

Stern'25) ガ「テトラヒドロベータナフチールアミ ン」(以下「テトラ」ト略龍セリ) 八都明二䯠溫 7 上

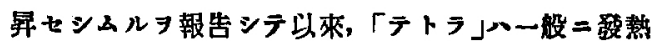
毒トシテ多數，學者二依り研究セラレ，其作用機轉 ニ關シテモ，或ハ中樞性ナリト主張シ (Burbouru. Wing 26), Cloetta u. Wuser ${ }^{27), ~ A i r i l a 28), ~ M o r i t a ~}{ }^{29)}$, Citron u. Leschke ${ }^{30)}$ ，橋本)，或八末梢性ナリト諭シ (Stern, lsenschniid ${ }^{31)}$, 阿南 ${ }^{32)}$, Takahashi33)), 諸家 ノ見解八區くタリ。

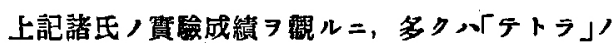

比較的大量 (10 mg以上) 7 用七, 夫レ二因ル體溫上

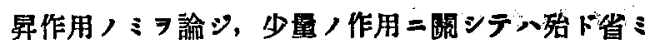

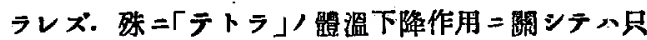
Otto u. Scott ${ }^{34)}$ ガ灰白結䬣 7 切斷シタル得「テトラ」

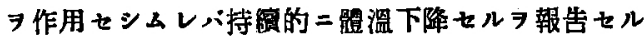
,ミ. 然ル =余八既=「アドレナロン」,「エフエト ソン」ニ於テ少量，場合二八體溫下隆作用著明ナル ヨ實驗シタルラ以テ，特二此點＝留意シ、「テトラ」

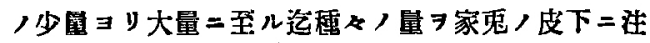

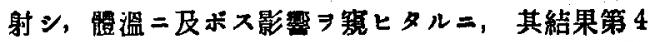
表ニ於アルガ如シ.

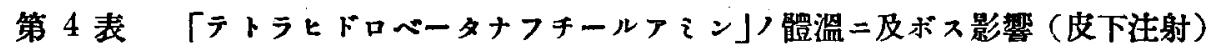

\begin{tabular}{|c|c|c|c|c|c|}
\hline 家兔䯣重 & (g) & 注 射量 (mg) & $\begin{array}{l}\text { 最大下降, 上昇度 } \\
=\text { 達スル迄 }\end{array}$ & 最大上降度 (C) & $\begin{array}{l}\text { 正常溫，復 } \\
\text { 几間 }\end{array}$ \\
\hline 2000 & $\hat{\jmath}$ & $2 \cdots$ & 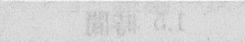 & $(-)$ & 0061 \\
\hline 2100 & $\hat{o}$ & ; & 1 時間 & $-0.5^{\circ}$ & 2.5 時間 \\
\hline 1980 & i & 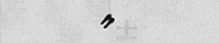 & & \pm & (2) \\
\hline 2050 & $\hat{o}$ & $"$ & & \pm & \\
\hline 2200 & 우 & " & thenter & $(+)$ & \\
\hline 1800 & ㅇ & 5 & 2 時間 & $-0.4^{\circ}$ & 2.5 時間 \\
\hline 1850 & $\delta$ & $"$ & 1.5 時間 & $-0.5^{\circ}$ & 2.5 時間 \\
\hline 1850 & q & $" 4$ & 2 時間 & $-1^{\circ}$ & 3 時間以上 \\
\hline 1900 & ㅇ. & $"$ & 1 時間 & $-0.3^{\circ}$ & 3.5 時間 \\
\hline 2000 & $\hat{\delta}$ & " & 1.5 時間 & $-0.4^{\circ}$ & 3 時間 \\
\hline 2350 & ㅇ & $"$ & 1.5 時間 & $-0.4^{\circ}$ & 3.5 時間 \\
\hline 1900 & $\hat{\delta}$ & " & & $(+)$ & \\
\hline 1700 & 우 & $\Rightarrow$ & 1.5 時間 & $+0.4^{\circ}$ & 1.5 時間 \\
\hline 2000 & $\hat{\delta}$ & $" 1+$ & 0.5 㭙間 & $+0.4^{\circ}$ & 2 時間 \\
\hline 2170 & ㅇ & $"$ & 1.5 時間 & $+0.6^{\circ}$ & 2.5 時間 \\
\hline 1750 & $\hat{0}$ & 10 & 0.5 時間 & $-0.3^{\circ}$ & 3 時間 \\
\hline 2000 & $\hat{\delta}$ & $"$ & & \pm & \\
\hline 2200 & $\hat{o}$ & $"$ & & \pm & \\
\hline 1850 & $\hat{o}$ & $\Rightarrow$ & 1 時間 & $+0.8^{\circ}$ & 2 時間 \\
\hline 1900 & 우 & $"$ & $"$ & $+0.3^{\circ}$ & 1.5 時間 \\
\hline 1950 & 우 & $"$ & " & $+0.7^{\circ}$ & 3.5 時間 \\
\hline 2100 & ㅇ & $"$ & $"$ & $+0.5^{\circ}$ & 1.5 時間 \\
\hline 2150 & $\hat{\delta}$ & $\Rightarrow$ & " & $+0.4^{\circ}$ & , \\
\hline 2170 & $\hat{\delta}$ & $\Rightarrow+11$ & 1.5 時閒 & $+0.3^{\circ}$ & 2 時間 \\
\hline 2000 & 우 & 20 & & \pm & \\
\hline 1800 & $\hat{o}$ & " & 2 時間 & $+0.8^{\circ}$ & 4 時間上上 \\
\hline 1980 & $\hat{\delta}$ & 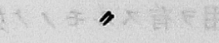 & 1 時間 & $+1.5^{\circ}$ & 5 時間 \\
\hline 2010 & $\hat{o}$ & $"$ & $"$ & $+1.3^{\circ}$ & 4 時間 \\
\hline 2000 & 우 & 50 & 2 時間 & $+2.5^{\circ}$ & 整死 \\
\hline 2000 & q & $"$ & 1 時間 & $+3.3^{\circ}$ & 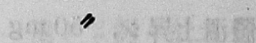 \\
\hline
\end{tabular}




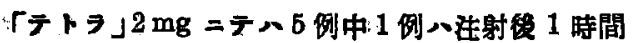

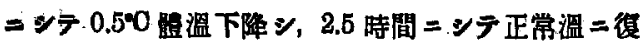

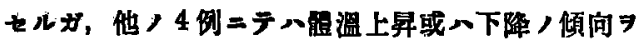
示シ, 又八确ド㷧霎ナカ 6 例ニテ 泩射得温溫 $0.3-1^{\circ} \mathrm{C}$, 本均 $0.5^{\circ} \mathrm{O}$ 下降シ, 多夕、注射後 1-2 時間ニシテ最低二下降シ，其役

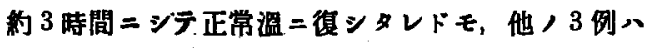
$0.4-0.6^{\circ} 0$ 鲩溫上开せり。

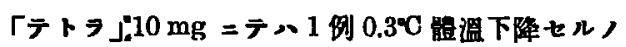
ミニシテ，多クハ體溫上昇シ（上昇度 $0.3-0.8^{\circ} \mathrm{C}$, 平

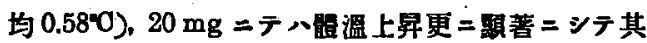

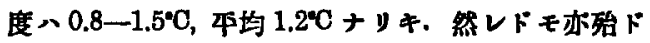

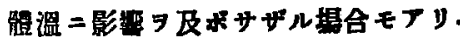

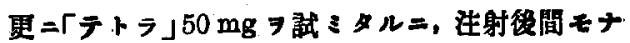
》體溫ハ著シク上昇シ(上昇度 $\left.2.5-3.3^{\circ} \mathrm{C}\right), 2-3$ 時 間ニシテ動物ハ䩹死セリ.

以上ノ如ク「テトラ」體温二及标作用入量的 關係，又八個性二传り著シク異レルガ如キモ，比較 的少量ニテ ハ體溫下降站二上昇，雨作用 ノニシテ, 而モ下降作用ノ如キハ, 從來多数 / 學者 ニョリ其䠦溫作用研究セラレタルニモ拘ラズ，尚ホ 看過セラレタルガ如シ. 比僌的大量ニテハ, 諸家，

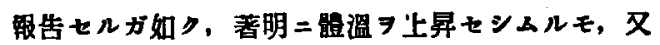
斯ル大量ニテモ何等，作用

\section{II 静 脉內注 射}

\section{1. 「アドレナリン」}

「ンドレナリン」ハ皮下注射ニテハ少量ハ體溫ヨ上 昇セシメ、大量八之ョ下降セシメタルガ，静䏡內注 射ニテ 八如何.

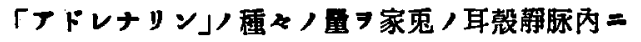

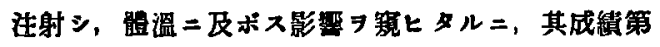
5 表二於ヶルガ如シ.

第 5 表「アドレナリン」ノ䯣溫二及ボス影辢（静脉內汁射）

\begin{tabular}{|c|c|c|c|c|c|}
\hline \multicolumn{2}{|c|}{ 家鬼霯重 (g) } & 注 射量 (mg) & 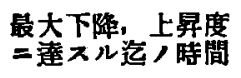 & 最大弪匴度 (0) & 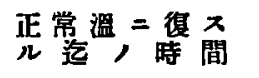 \\
\hline 2050 & $q$ & 0.02 & & $(-)$ & \\
\hline 2050 & 9 & , & 0.5 時間 & $+0.6^{\circ}$ & 2.5 時間 \\
\hline 2200 & $\delta$ & $n$ & 2 時間 & $+0.3^{\circ}$ & 2.5 時間 \\
\hline 1750 & $\delta$ & 0.05 & 0.5 時間 & $-0.7^{\circ}$ & 1.5 時間 \\
\hline 1950 & 7 & $"$ & 0.5 時間 & $-0.5^{\circ}$ & 4 時間 \\
\hline 2200 & $\hat{o}$ & , & 5 時間 & $-1.4^{\bullet}$ & 注射後 24 時間以內 \\
\hline 1900 & $q$ & 0.1 & 3 時間 & $-1^{*}$ & 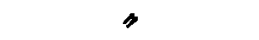 \\
\hline 2000 & $\delta$ & 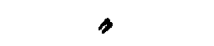 & 4.5 時間 & $-0.8^{\circ}$ & $\Rightarrow$ \\
\hline 2150 & $\hat{\delta}$ & 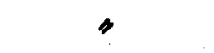 & 6 時間 & $-1^{\circ}$ & 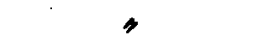 \\
\hline 1800 & $\delta$ & 0.5 & 3 時間 & $-1.4^{\circ}$ & 注射後 10 時間 \\
\hline 2050 & $\hat{\mathbf{z}}$ & 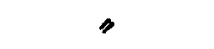 & 5 時間 & $-2.3^{\circ}$ & " 24 時間上上 \\
\hline 2130 & $\delta$ & 4 & & & 注射很間モナク整死 \\
\hline
\end{tabular}

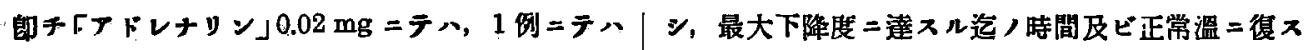

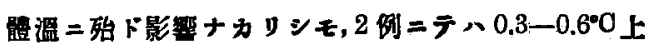

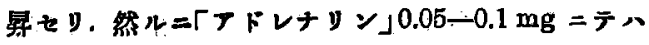
ル迄，時間ハ個性ニヨリ區々ナリキ。

更二「アドレナリン」0.5 mg 試ミタルニ、1刚入

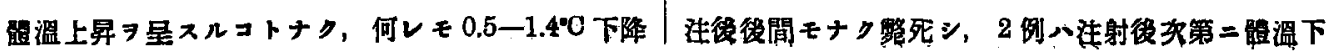




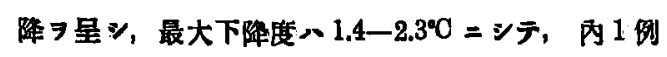
八注射挠 10 時間 =シテ正常溫二復セルモ，他八24 時間以後二於テ觜死セり。

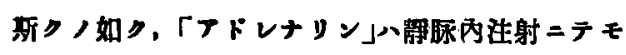

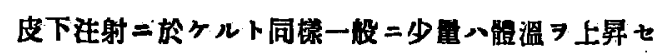

\section{2.「フドレナロン」}

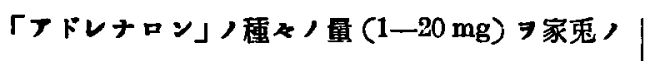
静示丙 $=$ 注射シ, 10 分每 $=$ 體溫 7 测定シタル二殆下

$$
\text { 3. 「ェフェドทン」 }
$$

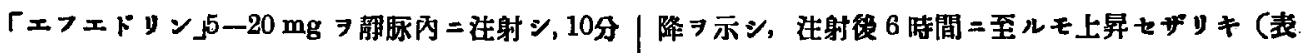

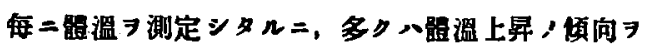
示スノミニシテ著明ナル铰化 $\ni$ 注射シタルニ, 1 例入注射後 1.5 時間 ニシテ $0.8 \bullet C$

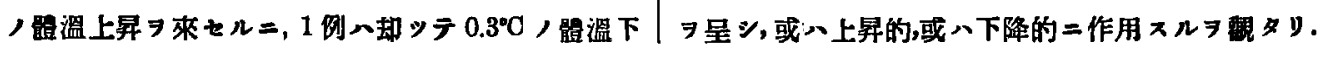

$$
\text { 4.「テトラヒドロペータナフキールプン」 }
$$

「テトラ」ノ 1-5 mg ヨ静豚內二注射シタルニ, 體 温二格剧ノ化 ノミン $0.5^{\circ} \mathrm{C}$ 體温上昇シ，生射後 2 時間 =シテ正常 温二復たり。

$10 \mathrm{mg}=$ テ 5 侧中 4 则 =テー $0.3-0.7 \%$, 平均 $0.4^{\bullet} \mathrm{C}$ 體温上昇シ, 多》八注射後 30 分ニシテ最高= 達シ，2-3 時間後二八正常溫二復シタレド，又政時 間モ高溫度习持概セルモノフリ。
更 $=20 \mathrm{mg}$ 习試 $ミ$ タ 盟溫上昇シ，後徐々二體温下降シッッ注射得 24 時間 以後ニ於テ死セり (表省略).

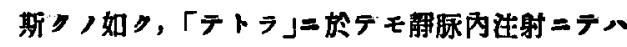
一般二作用弱クシテ，皮下生射，隆二思レタルガ如 キ少量二因ル能溫下降作用い㱠ド認メラレズ，大量 ニテハ同樣體罝ヨ上昇セシム.

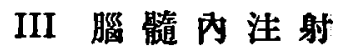

\section{A. 對 照 實 㜩}

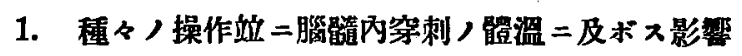

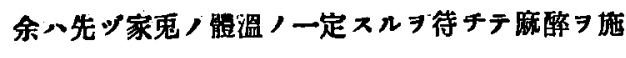
スコトナク之ヨ家鬼固定器(圆筒状) =固定シ, 溫刺

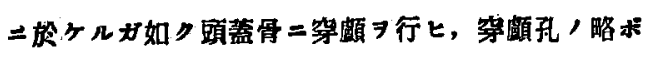
中央 $\exists$ ע注射針

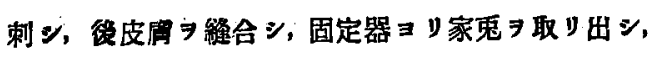
金網籍 $=$ 入

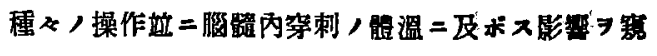

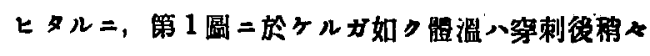
上昇，慣向习示スノミニシテ 3-4 時間迄心著明叶

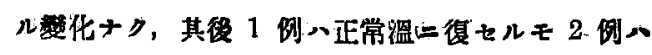
稍飞上昇 $\left(2\right.$ 例平均 $\left.0: 46^{\circ} \mathrm{C}\right)$, 近藤卜殆ド同漛，成 綽 $习$ 得々y。 


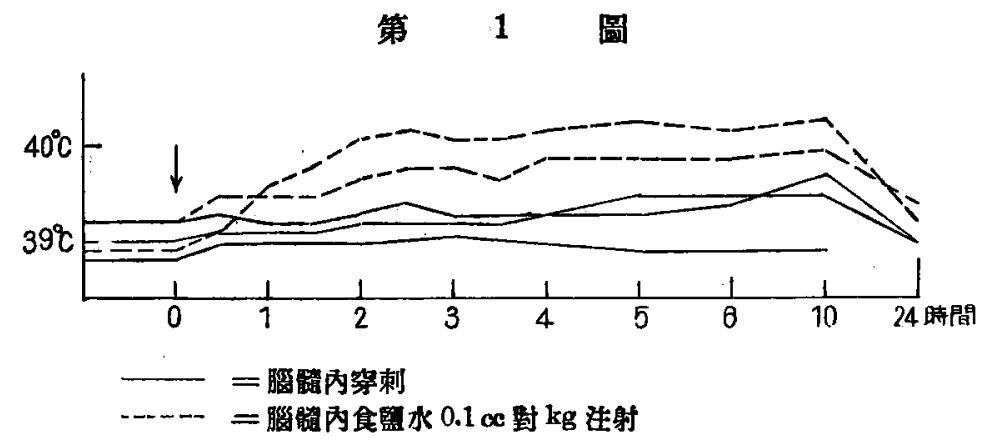

2. 食監水注射,體溫二及ボス影朗

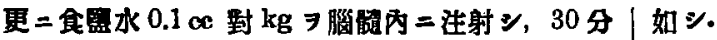

毎二路温 7 測定シタルニ，其成䋶第 6 表二於ルルガ

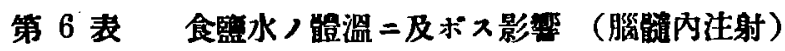

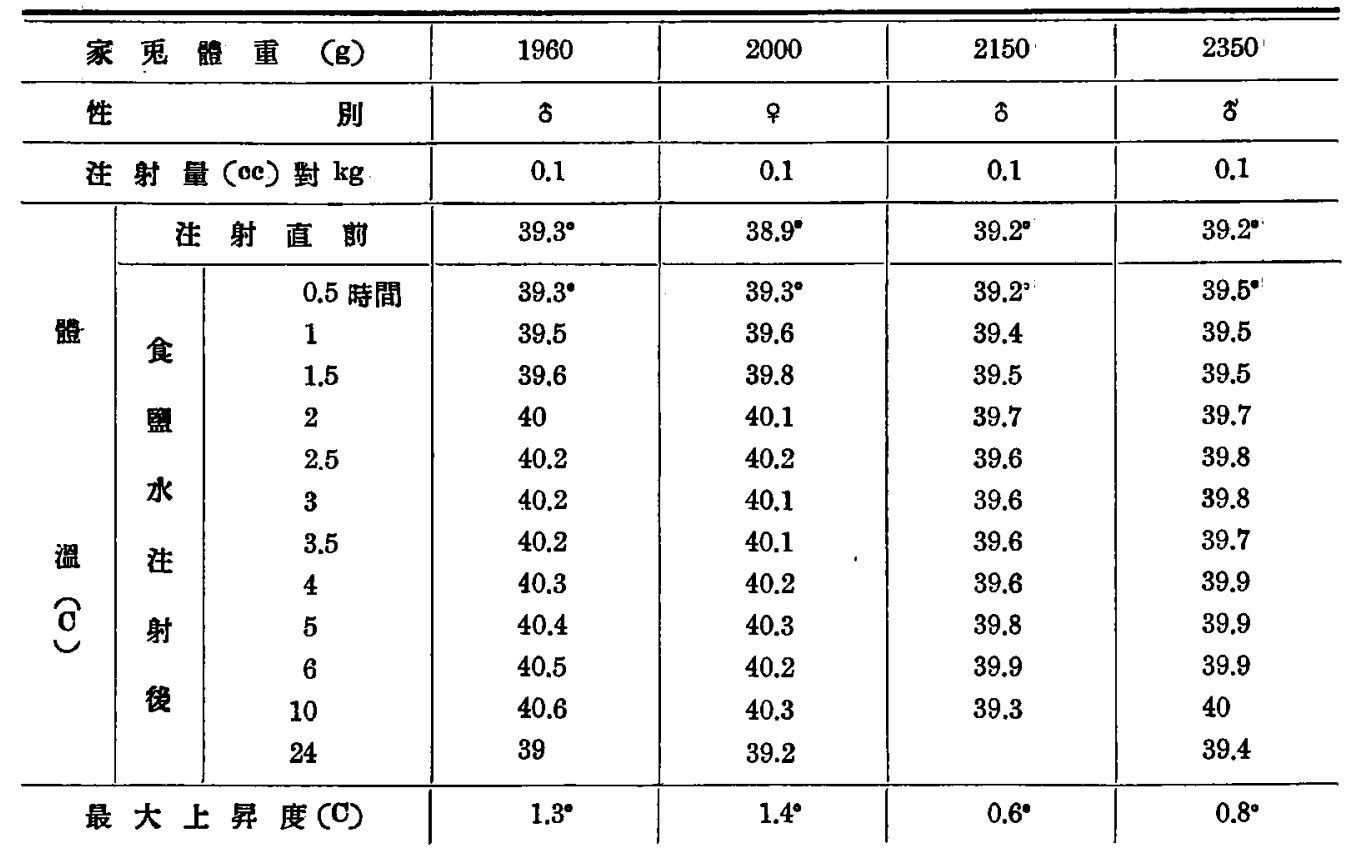

近藤八食監水

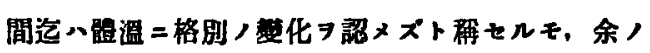

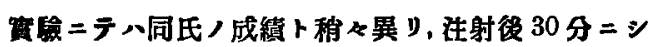

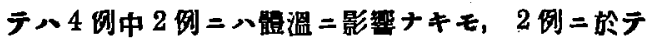

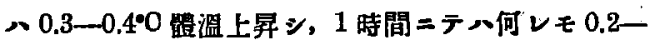
$0.7 \mathrm{C}, 1.5$ 時間 $=$ テ $0.3-0.9^{\circ} \mathrm{C}, 2$ 時間 $=テ ハ 0.5-$

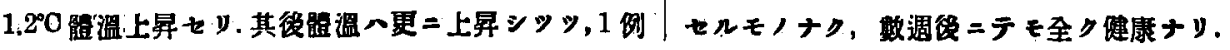




\section{B. 本耍驗 \\ 1. 「アトレナリン」}

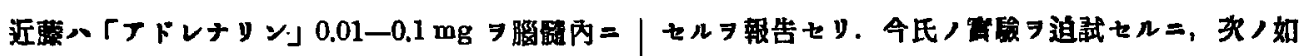

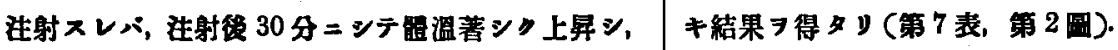

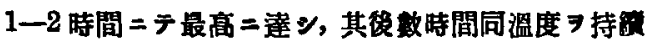

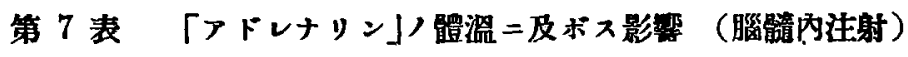

\begin{tabular}{|c|c|c|c|c|c|c|c|c|c|}
\hline \multicolumn{3}{|c|}{ 家 䨔 體 重 (g) } & 2000 & 2150 & 1980 & 2200 & 1800 & 1900 & 1900 \\
\hline \multicolumn{3}{|l|}{ 性 } & $\hat{\delta}$ & 우 & ? & 8 & $\hat{\delta}$ & $\delta$ & 9 \\
\hline \multicolumn{3}{|c|}{ 注射量 (mg) 到 $\mathrm{kg}$} & 0.02 & 0.02 & 0.05 & 0.05 & 0.1 & 0.1 & 0.1 \\
\hline \multirow{8}{*}{ 體 } & \multicolumn{2}{|c|}{ 注 射 直 的 } & $39^{\circ}$ & $38.8^{\circ}$ & $38.8^{\circ}$ & $38.7^{\circ}$ & $38.8^{\circ}$ & $39.1^{\circ}$ & $39.1^{\circ}$ \\
\hline & \multirow{3}{*}{7} & 0.5 時間 & $39.5^{\circ}$ & $39.6^{\circ}$ & $39.2^{\circ}$ & $38.7^{\circ}$ & $39.6^{\circ}$ & $39.1^{\circ}$ & $39.6^{\circ}$ \\
\hline & & 1 & 39.7 & 40 & 39.8 & 38.7 . & 40 & 39.1 & 39.8 . \\
\hline & & 1.5 & 39.6 & 39.8 & 39.5 & 39.1 & 39.9 & 39.4 . & 40 \\
\hline & $v$ & 2 & 39.6 & 39.8 & 39.3 & 39.5 & 40 & 39.6 & 39.8 \\
\hline & $t$ & 2.5 & 39.7 & 39.6 & 39.3 & 39.5 & 40 & 39.6 & 39.7 \\
\hline & $y$ & 3 & 39.8 & 39.6 & 39.3 & 39.6 & 40.2 & 39.6 & 39.7 \\
\hline & & 3.5 & 39.7 & 39.6 & 39.4 & 39.6 & 40.1 & 39.9 & 39.8 \\
\hline 温 & $L$ & 4 & 39.8 & 39.7 & 39.4 & 39.6 & 40.2 & 40.2 & 39.8 \\
\hline \multirow{4}{*}{$\stackrel{\mathfrak{o}}{\cup}$} & 注 & 5 & 39.9 & 39.9 & 39.6 & 39.8 & 40.2 & 40.6 & 39.8 \\
\hline & 射 & 6 & 39.9 & 39.8 & 39.6 & 39.8 & 40.2 & 40.8 & 39.7 \\
\hline & 後 & 10 & 39.9 & 39.6 & 38.7 & 39.8 & 40 & 40.4 & 38.8 \\
\hline & & 24 & 39.6 & 39 & & 39.1 & 39.3 & 39.1 & \\
\hline \multicolumn{3}{|c|}{ 最大上昇度 (C) } & $0.9^{\circ}$ & $1.2^{\circ}$ & $1^{\circ}$ & $1.1^{\circ}$ & $1.4^{\bullet}$ & $1.7^{\circ}$ & $0.9^{\circ}$ \\
\hline
\end{tabular}

第 $\quad 2$ 圖

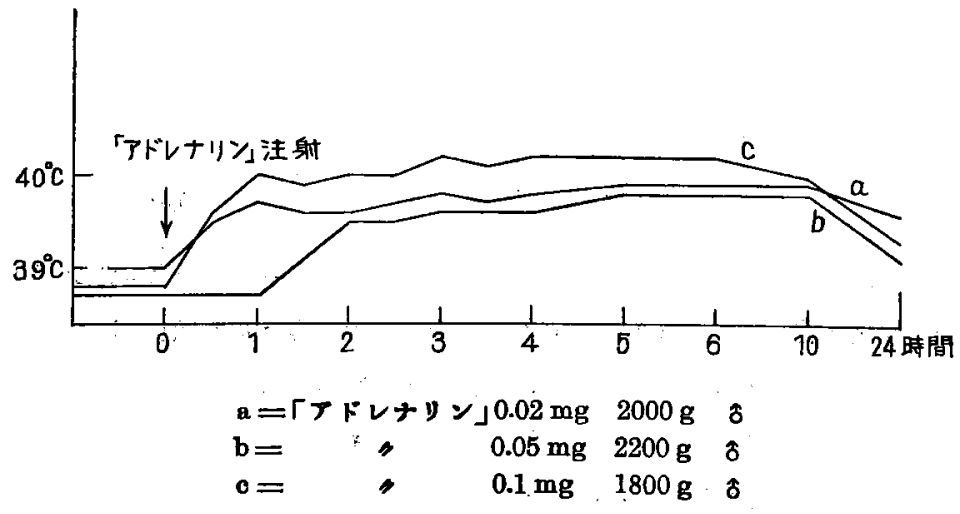

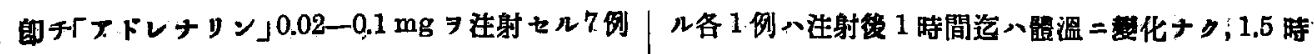

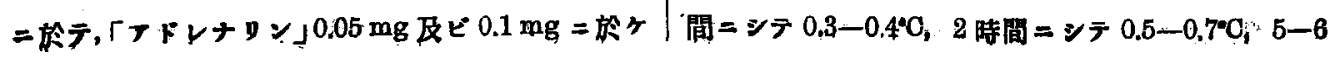




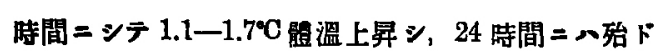
注射前，䯏温二復セリ.他，5例二テ八注射後 30 分 ニシテ $0.4-0.8^{\circ} \mathrm{C}, 1$ 時間ニテハ $0.7-1.2^{\circ} \mathrm{C}$ 體溫上昇

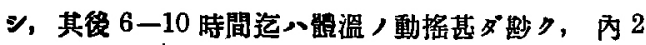
例 10 時間ニシテ，他 2 例ハ 24 時間ニシテ何レ モ注射前 $/$ 體温二復シタルニ, 倘木高溫度 7 保テル モノ1 侧アリキ.

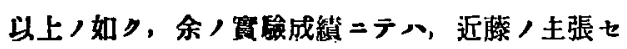

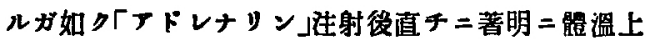
昇セルモハナレド，又注射後 1.5-2 時間迄八藷明ナ

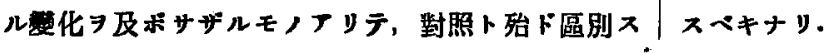

\section{2. 「アドレナロン」}

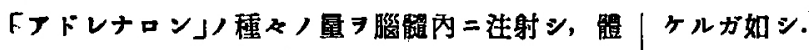

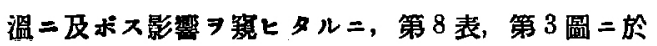

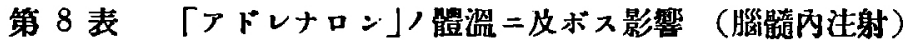

\begin{tabular}{|c|c|c|c|c|c|c|c|c|c|c|c|}
\hline \multicolumn{4}{|c|}{ 家象體 重 (g) } & 1850 & 2100 & 2200 & 1800 & 1900 & 2000 & 2000 & 2250 \\
\hline \multicolumn{2}{|c|}{ 性 } & & 剧 & 우 & 우 & $\hat{\delta}$ & 우 & $\hat{o}$ & $\hat{o}$ & $\hat{o}$ & ㅇ \\
\hline \multicolumn{4}{|c|}{ 注射量(mg) 對 $\mathrm{kg}$} & 2 & 2 & 2 & 5 & 5 & 5 & 5 & 5 \\
\hline \multirow{6}{*}{ 䯠 } & & 射 直 & 前 & $39.4^{\circ}$ & $39.2^{\circ}$ & $39.4^{\circ}$ & $39.3^{\circ}$ & $39.1^{\circ}$ & $39.2^{\circ}$ & $39.2^{\circ}$ & $39^{\circ}$ \\
\hline & \multirow{3}{*}{$\bar{T}$} & 0.5 & 時間 & $39.1^{\circ}$ & $39.3^{\circ}$ & $39.5^{\circ}$ & $38.2^{\circ}$ & $38.3^{\circ}$ & $38.8^{\circ}$ & $38.9^{\circ}$ & $38^{\circ}$ \\
\hline & & 1 & & 39.4 & 39.8 & 39.8 & 38.6 & 38.2 & 39 & 38.7 & 38 \\
\hline & & 1.5 & & 39.9 & 40.2 & 39.8 & 39 & 38.2 & 39.1 & 39 & 38 \\
\hline & $F$ & 2 & & 40.1 & 40.5 & 39.8 & 39.2 & 38.2 & 39.1 & 39.2 & 37.7 \\
\hline & $\checkmark$ & 2.5 & & 40.1 & 40.5 & 39.8 & 39.4 & 38.5 & 39.4 & 39.5 & 37.7 \\
\hline \multirow{5}{*}{$\begin{array}{l}\text { 溫 } \\
\stackrel{\mathrm{C}}{\cup}\end{array}$} & \multirow{2}{*}{ 口 } & 3 & & 40.3 & 40.8 & 39.8 & 39.5 & 38.5 & 40 & 39.7 & 38 \\
\hline & & 3.5 & & 40.3 & 41 & 39.9 & 39.7 & 39 & 40 & 39.7 & 38 \\
\hline & ᄂ & 4 & & 40.5 & 41 & 39.9 & 40.6 & 39.5 & 40.3 & 39.8 & 38.1 \\
\hline & \multirow{4}{*}{$\begin{array}{l}\text { 注 } \\
\text { 射 } \\
\text { 後 }\end{array}$} & 5 & & 40.7 & 41 & 39.9 & 41 & 40 & 40.7 & 40.1 & 38.2 \\
\hline & & 6 & & 40.9 & 41 & 40 & 41.3 & 40 & 40.7 & 40.2 & 38.2 \\
\hline & & 10 & & 40.8 & 40.5 & 40 & 41.3 & 40.4 & 40.5 & 40 & 39.5 \\
\hline & & 24 & $\sqrt{1}$ & hiche & 38.8 & 39.1 & 40.6 & 38.9 & 39.6 & 40.3 & 39.3 \\
\hline \multirow{2}{*}{\multicolumn{4}{|c|}{ 最大上降 $($ 一昇 $(+)$ 度 (C) }} & $-0.3^{\circ}$ & $+18^{\circ}$ & $+06^{\circ}$ & $-1.1^{\circ}$ & $-0.9^{\circ}$ & $-0.4^{\circ}$ & $-0.5^{\circ}$ & $-1.3^{\circ}$ \\
\hline & 上易 & $(+)^{\infty}$ & & $+1.5^{\circ}$ & & & $+2^{\circ}$ & $+1.3^{\circ}$ & $+1.5^{\circ}$ & $+1.1^{\circ}$ & $+0.5^{\circ}$ \\
\hline
\end{tabular}

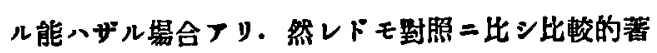

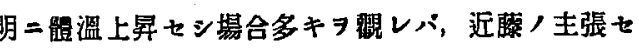
ルガ如ク「テドレナリン」ハ中樞性體温上昇作用 7 有 スルノノ如シ。

㑇ホ「ナドレナリン」ハ0.1\%，溶液ナレバ注射量 ～ 0.1 c 對 $\mathrm{kg}$ ト定メタルヨ以テ,「アドレナリン」 $0.1 \mathrm{mg}$ 以上ハ用七得ザリキ. 且 $0.1 \mathrm{mg} /$ 注射

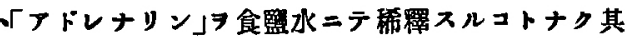

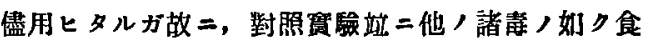

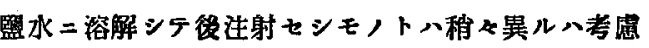




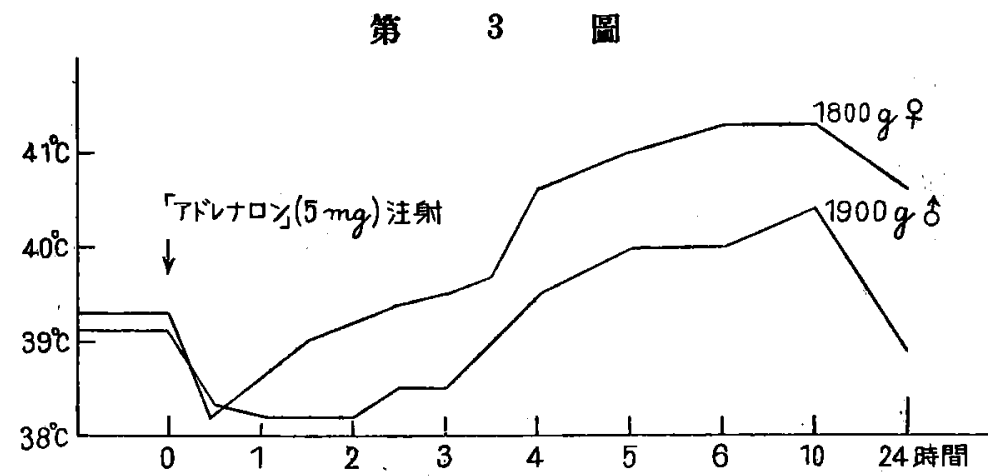

臫チ「ナドレナロン」1-2 $\mathrm{mg}=テ ッ 5$ 例中 4 例

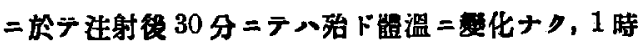

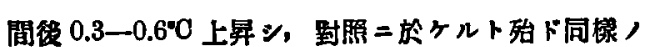
经過ナリシモ, $2 \mathrm{mg}$ 二於ヶル1例八注射後 30 分二

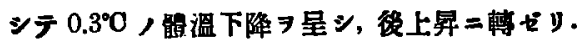

「ナドレナロン」 $5 \mathrm{mg} ニ テ ハ$ 法射後 $0.4-1.3^{\circ} \mathrm{C}, 5$ 列本均 $0.8^{\circ} \mathrm{C}$ 體温下降シ，摞上昇二移行七》。其經 過 7 毁ル二，注射後 30 分ニシテ $0.3-1.1^{\circ} \mathrm{C}, 1$ 時間 ニシテ 0.3-1C 䯏溫下降シ注射後 2-3 時間 =ハ多

$$
\text { 3. 「エフェドンン」 }
$$

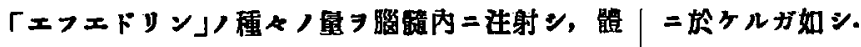

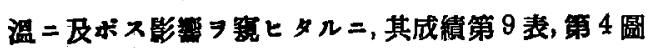

第 9 表「エフェドリン」ノ體溫二及ボス影裂（腦筑內注射）

\begin{tabular}{|c|c|c|c|c|c|c|c|c|c|c|c|c|}
\hline 家 & 鬼 & 疽 董 (g) & 1900 & 2100 & 2100 & 1800 & 2000 & 2400 & 1900 & 1920 & 2000 & 2000 \\
\hline 性 & & 別 & \% & $\hat{o}$ & q & 9 & q & 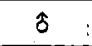 & q & q & $\delta$ & o \\
\hline & 村哩 & mg) $\mathrm{kg}$ & 0.5 & 0.5 & 0.5 & 1 & 1 & 1 & 2 & 2 & 5 & 5 \\
\hline & & 射 直 㓷 & $38.9^{\circ}$ & $39.2^{\circ}$ & $39.8^{\circ}$ & $39^{\circ}$ & $39.7^{\circ}$ & $38.7^{\circ}$ & $39.1^{\circ}$ & $39^{\circ}$ & $39.2^{2}$ & $39^{\circ}$ \\
\hline \multirow{5}{*}{ 罡 } & & 0.5 時 & $38.9^{\circ}$ & $38.9^{\circ}$ & $39.5^{\circ}$ & $38.4^{\circ}$ & $39^{\circ}$ & $38^{\circ}$ & $38.5^{\circ}$ & $38.7^{\circ}$ & $37.4^{\circ}$ & $38.1^{\circ}$ \\
\hline & ᄀ & 1 & & 39.2 & 39.5 & 38 & 39.3 & & 38 & 38.4 & 37.5 & ' 38.2 \\
\hline & 工 & 1.5 & 39,3 & 39.3 & 39.5 & 38.5 & 39.8 & 38.3 & 38 & 38. & 8.2 & 38.5 \\
\hline & 7 & 2 & 39. & 39.3 & 39.5 & 39 & 40.2 & 38 & 39 & 38 & 3.8 & 38.7 \\
\hline & \pm & 2.5 & & 39.4 & 40.1 & 39.2 & 40.6 & & 39 & 38 & & 39.1 \\
\hline & 5 & $\mathbf{3}$ & & 39.6 & 40.1 & 39. & 40.8 & & 39 & 39. & 39.3 & 39.2 \\
\hline \multirow[b]{2}{*}{ 淔 } & I) & 3.5 & & 39.6 & 40. & 39.3 & 41 & 38.9 & 39.7 & 39. & 39.4 & $\begin{array}{l}39.5 \\
\end{array}$ \\
\hline & Ĺ & 4 & 39. & 39.6 & 40.3 & 39. & 41 & & 40 & 39.6 & 39.8 & 39.8 \\
\hline \multirow{4}{*}{ d } & 注 & 5 & & & 40. & 39. & 40.9 & 39 & 40.2 & 39.8 & 40 & 40.1 \\
\hline & 射 & 6 & & & 40 & 39 & 41 & & 40.1 & & 2 & 40.6 \\
\hline & 盽 & 10 & 40 & 39.6 & 41 & 40.1 & 40.8 & 39 & 40 & 4 & 40.1 & 40.9 \\
\hline & & 24 & & 39.2 & 39.8 & & & 38.7 & & 39.3 & 39.4 & 40 \\
\hline & & & $-1.1^{\circ}$ & -0.3 & -0.3 & $-1^{\circ}$ & $\begin{array}{r}-0.7^{\circ} \\
+1.3^{\circ}\end{array}$ & $\begin{array}{r}-0.7^{\circ} \\
+1.2^{\circ}\end{array}$ & $\begin{array}{l}-0.6^{\circ} \\
+1.1^{\circ}\end{array}$ & $\begin{array}{l}-0.6^{\circ} \\
+1^{\circ}\end{array}$ & $\begin{array}{l}-1.8^{\circ} \\
+1^{\circ}\end{array}$ & $\begin{array}{l}-0 \\
+1 .\end{array}$ \\
\hline
\end{tabular}




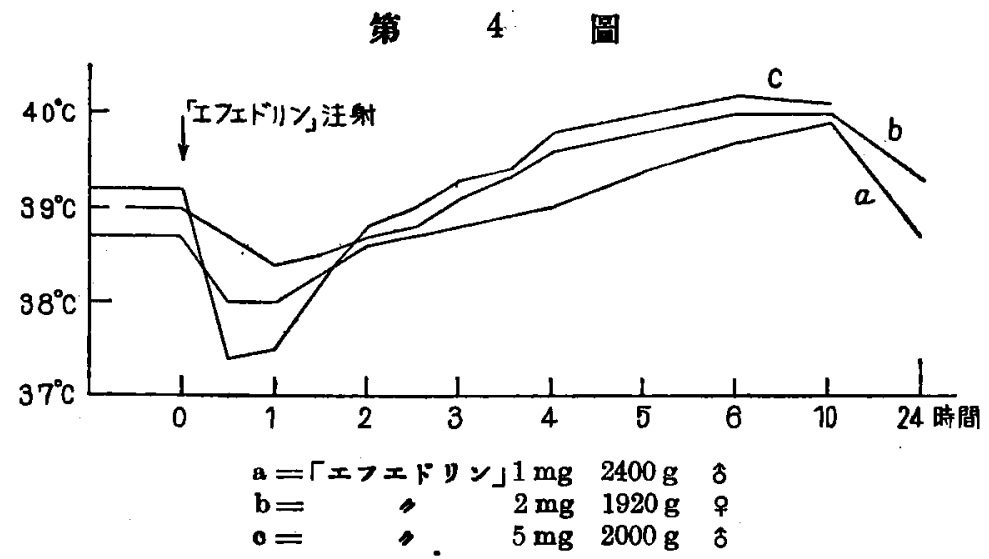

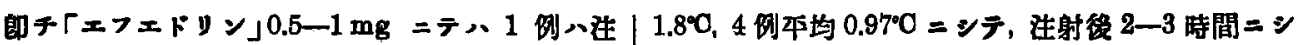

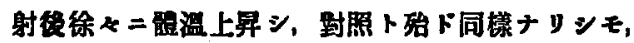
$0.5 \mathrm{mg}=$ 於ヶル 2 例入注射後 30 分ニシテ $0.3^{90} \mathrm{C}, 1 \mathrm{mg}$

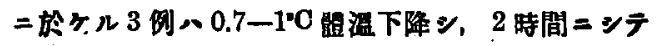

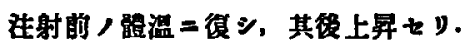
テ正常温二復シ，其拣體温上昇々 y.

即チ「ェフェドンン」八皮下泩射二テハ其能温下

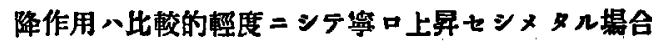

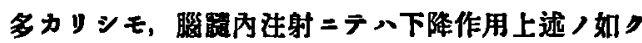

「メフェドン」2-5 mg ニテハ注射役 30 分乃至 「ナドレナロン」ノ夫レヨリモ更二㟲著ニシテ，作用

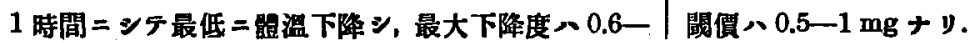

$$
\text { 4.「テトラヒドロベータナフチールアにン」. }
$$

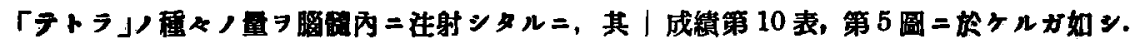

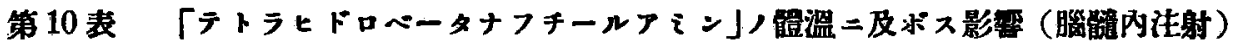

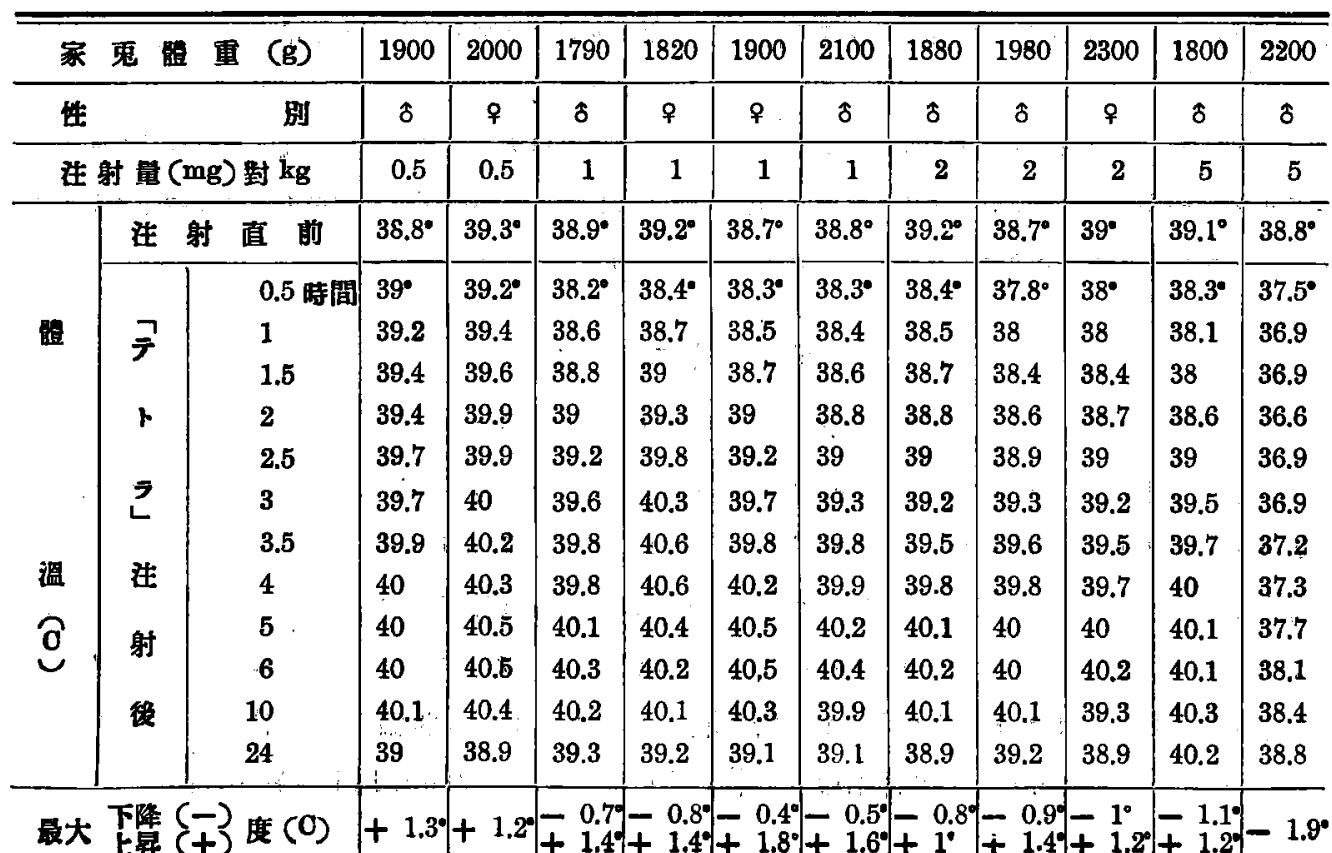




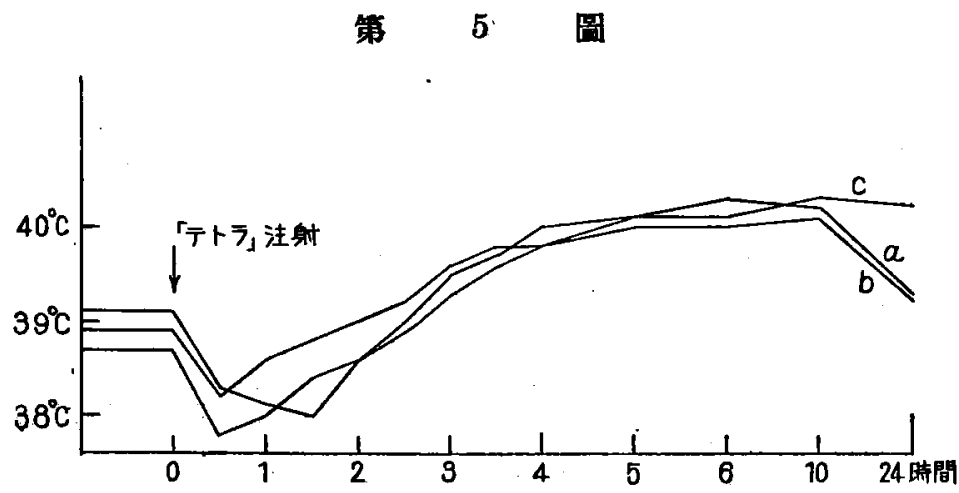

$$
\begin{aligned}
& \mathrm{a}=\Gamma \text { トラヒドロヘータナフチールナミン」1 mg } 1780 \mathrm{~g} \\
& \mathrm{~b}=2 \mathrm{mg} 1980 \mathrm{~g} \delta \\
& 0=\quad 5 \mathrm{mg} 1800 \mathrm{~g} \text { \% }
\end{aligned}
$$

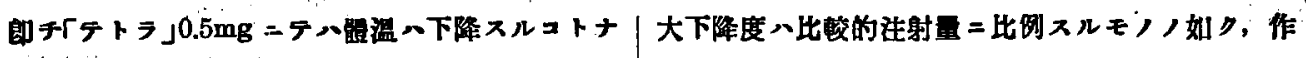

$\eta ，$ 注射後 1-1.5 時間 $コ$ 上昇ン，對照卜殆ド同㧼 ナリシモ, $1 \mathrm{mg}=$ テ、注射後 30 オニシテ $0.4-0.8^{\circ} \mathrm{C}$,

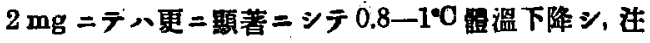
射後 $2-3$ 時間 ニシテ正常温 $=$ 復シ，更二上昇セり.

「テトラ」5 mg ニテハ注射後 1.5 及ビ 2 時間ニシ テ 1.1・ 及ビ $1.9^{\circ} \mathrm{C}$ 䯏溫下降シ，前者八其绻 1 時間 $=シ$ テ注射的，體温二得シタルモ，後者心注射後 10 時間

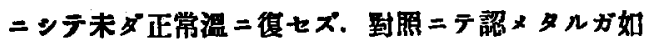
キ胃淈上昇モナク，泩射後 20 時間ニシテ正常温二復 七).

上述ノ如ク、「テトラ」ハ「マドレナロン」「エフ

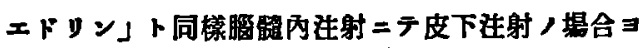
リモ更二著明二䯏溫 ヨ下琎セシムルモノニシテ，最
用閥偩 $1 \mathrm{mg}$ ナע.

何ホ上記諸毒中「ナドレナロン」「エフェドリン」

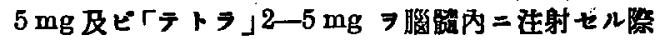
八居飞動物八直千二則卧位トナリ，正常位习保持 得ズ. 眼球八著シク笑出シ，苦䦥，肤 フリ. 斯几定狀一注射直後二於テ最モ甚ダシキモ,

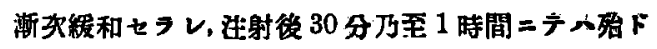
正常時卜異ラス゚. 然レドモ亦全然斯ク，如キ作用 呈セザモノナリ. 文更二少量二テ眼球稍に笑出七

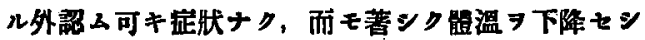

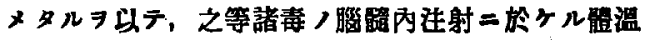

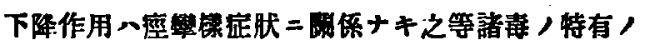
作用ナリト謂フヨ得ベン.

\section{總括涉二考察}

上上ノ賽驗成績 =基キ，之等交感神經毒，䯤溫作用 7 比較スルニ，

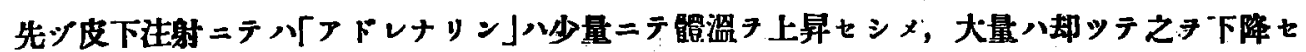

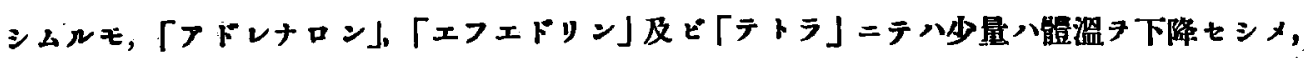

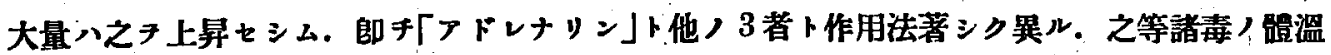

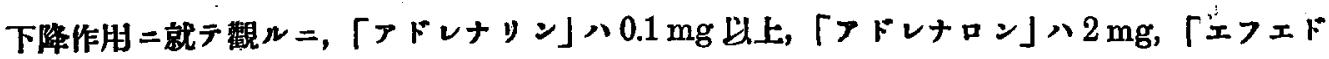

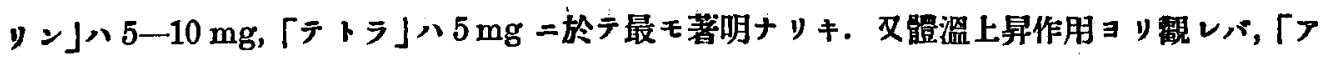

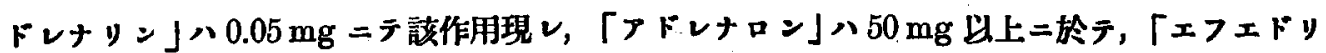




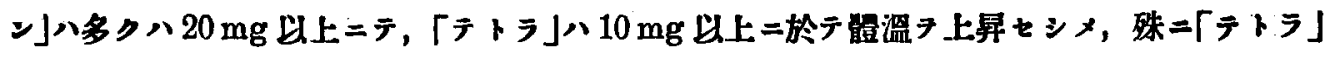

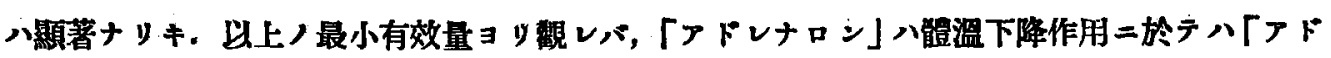
レナリン」ノ約 1/10-1/20ナレドモ，體温上昇作用二於テ 八約 1/1000二當ル。本成績ハ「アド

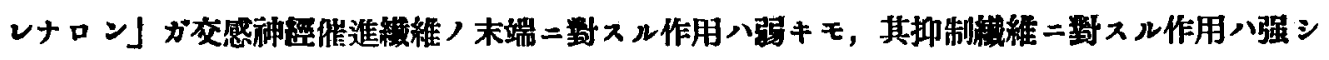
ト謂へル谷, 藤田等ノ成踫卜興味アル一致タ示ス.

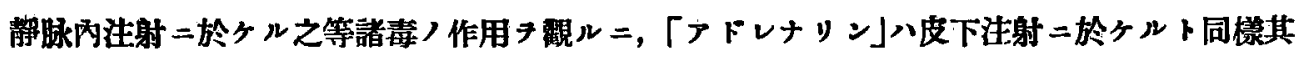

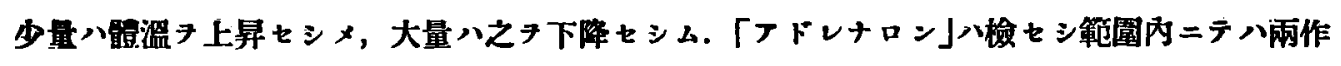

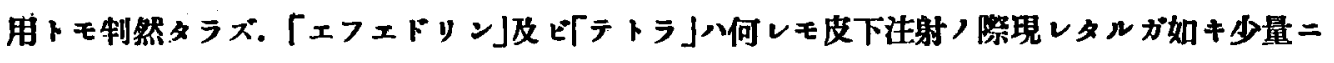
因ル體温下降作用ハ不著明ニシテ，一般二前者八體温上昇〉傾向 呈シ，後者八著明二之ョ上 昇セシム.

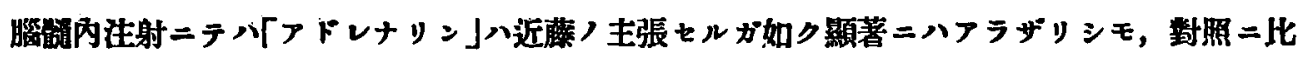
シ多ク八體溫ヨ上昇セシムルガ如ク，又對照ト殆ド區別シ得ザル場合モフリ．然レドモ，體溫

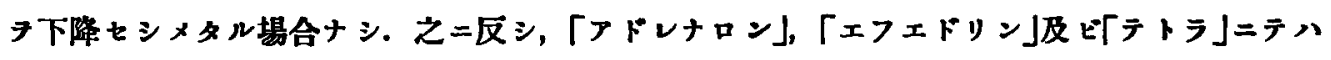
何レモ注射後體溫

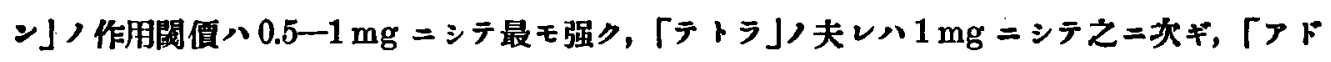
レナロン」ハ5 $\mathrm{mg}$ ニシテ最モ弱シ.

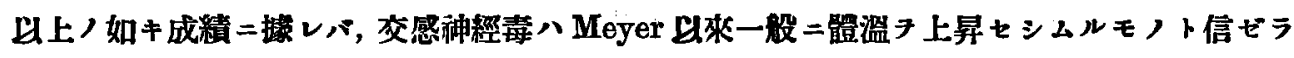

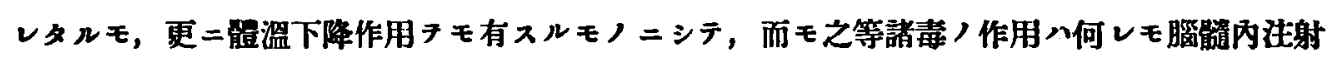

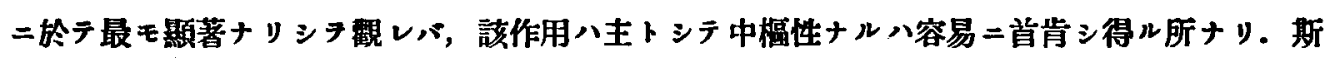
クテ交感神經系統トMeyer ガ假定シテ 以柬副交感神經系統二屬スト見做サレタル冾中愠ト， 間二特殊ノ關係ノ存スルコトモ办推測スル二難かラズ. 然ラバ所謂冷中樞い交感神經站二副交

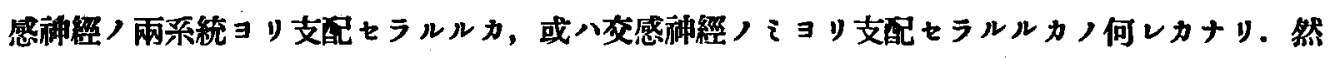

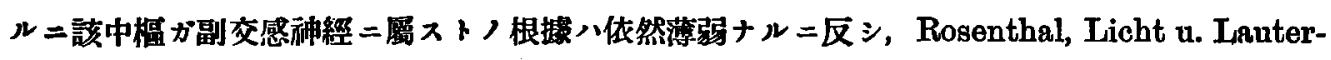
bach 立 $=F u j i i^{35)}$ ，諸氏ハ一般二中榀性副交感神縃毒トシラ知ラレタル「ピクロトキシン」,

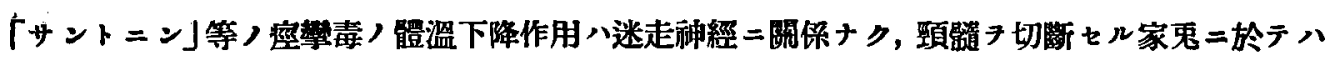

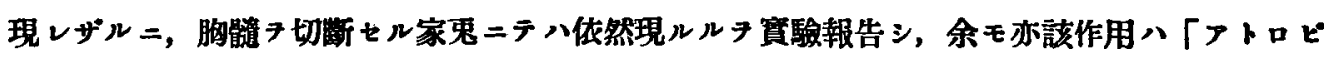

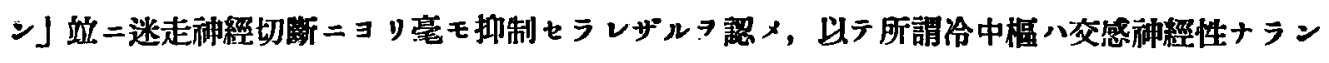
ト推論七り．今本䁈驗成精二據レバ，斯クノ如キ見解ノ篮ヶ正當ナルタ信ズルモノナリ.

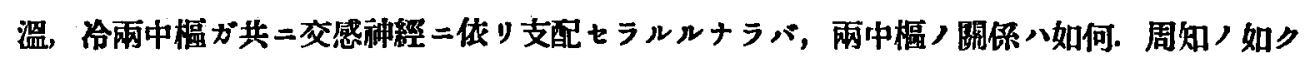

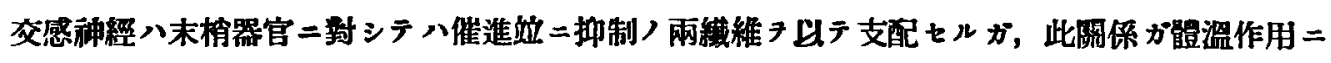

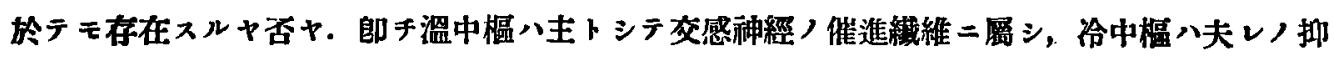
制蟣維二虽スルニアラザルカ.コハ今後う攻究スベキ興味アル問題ナリ．然レドモ之等交感神

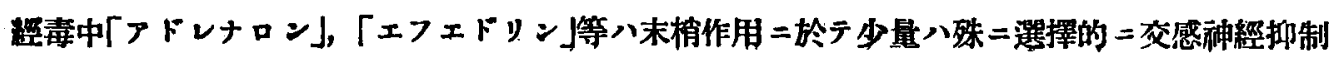




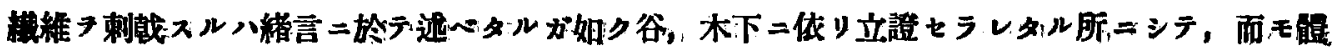

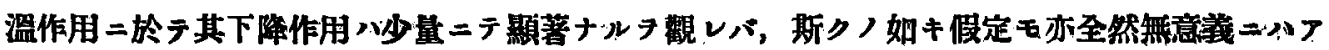
ラザルベシ.

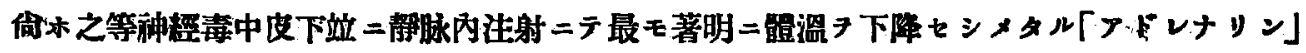

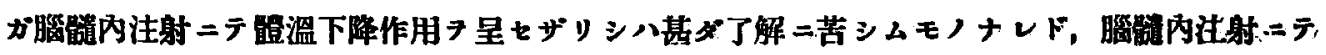

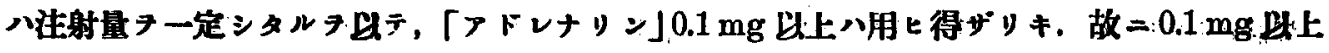

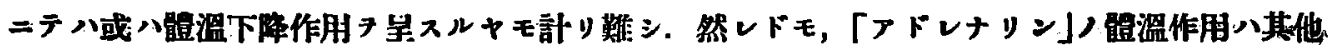

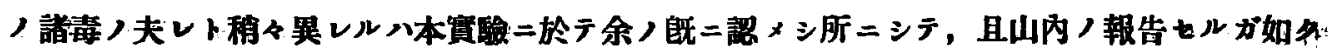

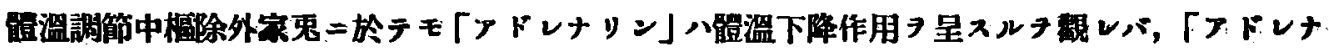

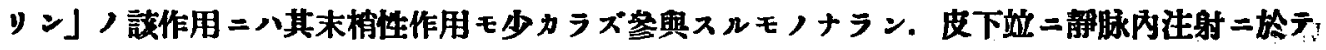

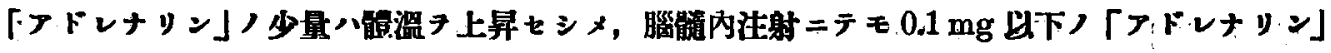

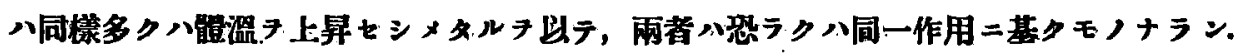

\section{結 論}

之等ノ交感神經毒八何レモ體溫上昇作用ト下降作用トアリ，適用部位及ビ分量二侇り其作用 法暴り，及一定ノ條件ノ下二於テモ動物ノ個性ニヨリ差異アリテ，或八前作用又八後作用子咞 ス. 然レドモ些細二覾察スル二其間略ボ一定ノ規則アルフ認ム．即于

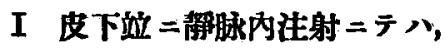

1.「アドレナリン」ハ少量ニテ體溫ヌ上昇セシメ，大量ニテハえョ下降セシム．雨作用トモ 静脉网注射ノ方皮下注射ノ場合ヨリ著明ナリ。

2. 之二反シ,「アドレナロン」,「エフェドリン」,「テトラヒドロベータナフチールフミン」

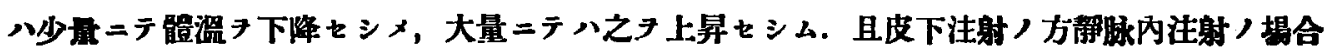
ヨコ㩆著ナり。

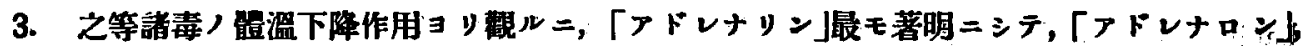
「テトシヒドロベータナフチールブン」えニ次ギ,「エフェドリン最モ弱シ. 其際最小有效量 ヨリ覞レパ,「フドレナリン」作用强度へ「アドレナロン」 10-20倍ナリ.

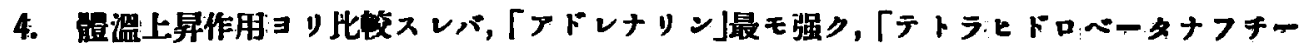

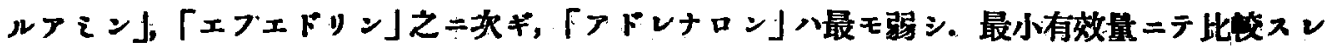

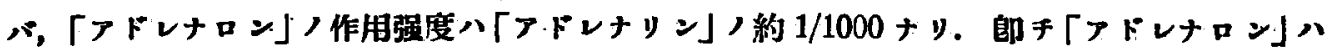
「アドレナリン」比スレバ體温与昇作用ヨリモ下降作用ノ方比較的强シ.

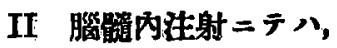

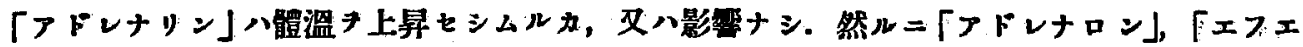

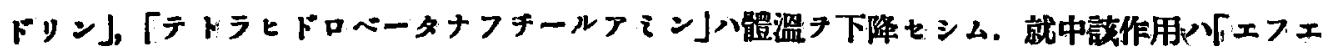


ドン」ニテ最モ著明ニシテ，「テトラヒドロベータナフチールフミン」之ニ次ギ,「フドレナロ ン」ニ於テ最モ弱シ.

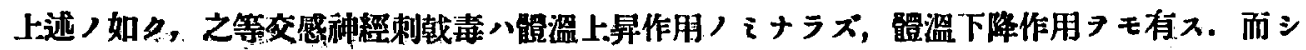
テ之等ノ作用ハまトシテ中樞性ノ邚シ，然レドモ「アドレナリン」ノ中楅性體溫抑制作用八直接 證明困難ナリキ. 恐ラク「アドレンリン」ハ中樞的二該作用テ有スレドモ，亦末梢性作用モ重大

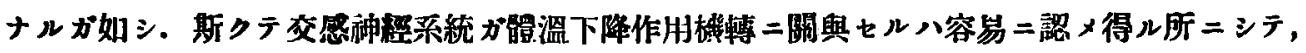

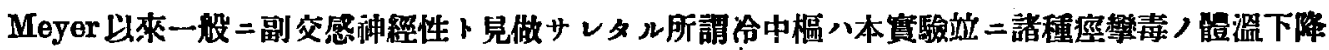
作用二開 スル Rosenthal, Licht u. Lauterbach 站=Fujii 及ビ余ノ賽駸成樍等 八湓々交感神經性ナルコト或二近シ。

\section{文辡}

1) H. Meyer, Verhandlung des deutsch. Oongresses f. inner. Med. Bd. 30, S. 15, $1913 . \quad$ 2) 槚本,

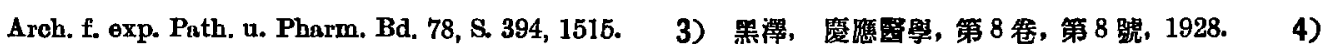

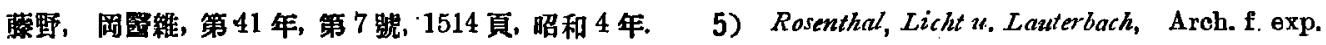
Path. u. Pharm. Bd. 106, S. 233, 1925. 6) 谷, 岡雾雜, 第 42 年, 第 11 號。2769 頁, 昭和 5 年. 7)

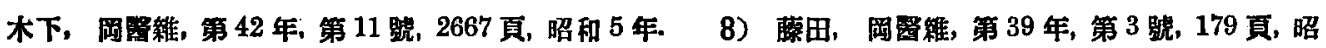

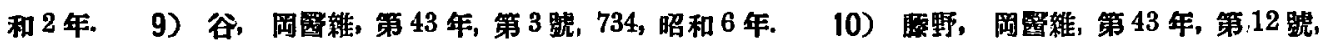

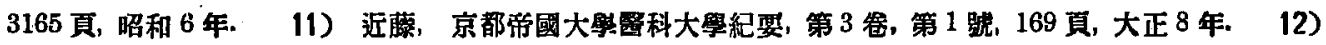
Aronsolion u. Sachs, Pflüger's Aroh. Bd. 37, S. 232, 1885. 13) Freund u. Grafe, Arch. f. exp. Path. u. Pharm. Bd. 67, S. 55, 1912 . 14) Adler, Areh. exp. Path. u. Pharm. Bd. 87, S. 406, 1920. 15)

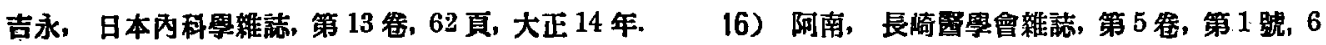
頁。昭和 2 年. 17) Wolownik, Arch. f. Puth. Anat. Bd. 180, S. 225, $1905 . \quad$ 18) Abderhalden,

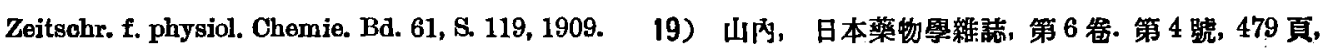

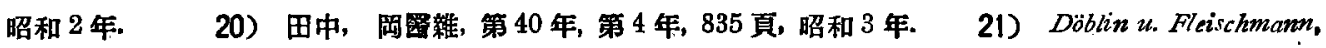
Zeitschr. f. klin. Med. Bd. 78, S. 275, $1913 . \quad$ 22) Cloetta u. Waser, Arch. f. exp. Path. u. Pharm. Bd.

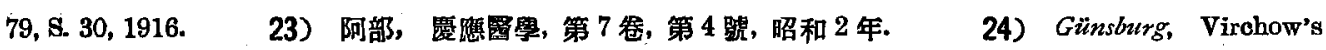
Archiv. Bd, 124, S. 75, 1891. z. n. Hashimoto. 25) Stern, Virchow's Archiv. Bd. 115, S. 14, 1889. Bd. 117, S. 418, 1889. 26) Barbour u. Wing, Journ. of Pharm. and Exp. Therap. Vol. 5, P. 105, 1913. 27) Cloetta u. Waser, Areh. f. exp. Path. u. Pharm. Bd. 73, S. 436, 1913. 28) Airila, Arch. intern. de Pharmakodyn. et de Therap. Vol. 23, S. 453, 1913 . 29) Morita, Arch. f. exp. Path. u. Pharm. Bd. 78, 8. 218, 1915. 30) Citron u. Leschke, Zeitschr. f. exp. Path. u. Therap. Bd. 14, S. 379, 1913. z. n. Arch. f. exp. Path. 1. Pharm. Bd. 85, S. 282, $1920 . \quad 31$ ) Ischenschmid, Aroh. f. exp. Path. u. Pharm. Bd. 85, S. 271, 1920. 32）阿南，長崎瑿學會雜誌，第 5 管，第 5 號，696 頁，昭和 2 年. 33）Takahashi， Tohoku J. exper. Med. Bd. 12, S. 397-405, 1929. 34） Otto u. Scott, Jonrn. of exp. Med. Bd. 9, Nr. 6, 1907. z. n. Arch. f. exp. Puth. u. Pharm. Bd. 85, s. 282, 1920. 35) Fujii, Arch. f. exp. Path. u. Pharm, Bd. 133, S. 242, 1928. 